\title{
Adoption of Health and Nutritional Practices by Farm Women
}

\author{
S.P. Dhoke ${ }^{1}$, Y.B. Shambharkar ${ }^{2}$, V.G. Dhulgand ${ }^{1 *}$ and R.G. Nair ${ }^{1}$ \\ ${ }^{1}$ Department of Extension Education College of Agriculture, Parbhani, Maharashtra, India \\ ${ }^{2}$ Department of Extension Education College of Agriculture, Akola, Maharashtra, India \\ *Corresponding author
}

\section{A B S T R A C T}

\section{Keywords}

Adoption, Health and nutritional practices,

Farm women

Article Info

Accepted:

14 December 2017

Available Online:

10 January 2018
This study was purposively conducted in Achalpur taluka of Amravati district for the Knowledge and Adoption of Health and Nutritional Practices by Farm Women. 150 farm women were selected from 10 selected villages by using random sampling method. The findings of this study can be concluded that maximum number of the respondents were adopted the health and nutritional practices at medium extent.

\section{Introduction}

According to WHO, "Health is the state of complete physical, mental and social well being and not merely and absent of disease or infirmity.'In the recent year, this statement has been amplified to include ability, to lead a socially and economically productive life. Recently a broader concept of health has been emerging that improving the quality of life which is an essential component.

The energy requirement is defined as the level of energy intake from food that balances energy expenditure when the individual has a body size and composition and level of physical activity, consistent with long-term good health, also allowing for maintenance of economically essential and socially desirable activity. In children and pregnant and lactating women, it includes the energy needs associated with the deposition of tissues or secretion of milk at rates consistent with good health

From time Immemorial, women play different role in their home activities, as wives in their personal lives with their husband, as mother with the responsibilities for the development of their children and as a home maker in charge of the operation in their home. Indian women more especially the rural women play multifarious socio-economic roles inside as well as outside the home. She share abundant 
responsibilities and perform a wild spectrum of duties. In running household and the family, like child care, collection of fodders and fuels, cooking, fetching water etc., as well as attending farm activities, dairy, animal husbandry, an extending helping hand in rural artisanship and handicrafts. Therefore consumption of energy by the farm women needs to know to maintain good health.

\section{Materials and Methods}

The study was conducted in Amravati district of the Vidarbha region of Maharashtra state. Achalpur Panchayat samit was purposively selected based on more number of primary health centre in Amravati district. Achalpur taluka comprises of 68 villages out of which 10 villages were selected randomly based on having Primary Health Centre.

The main objectives of the study was to measure the knowledge and adoption of farm women about health and nutritional practices which includes the different practices like, personal hygiene, sanitation, care of surrounding, care and diet of the person, food preservation. Therefore, it was felt necessary that the respondents in the study area must have the sufficient information of the family life. So, it was decided to select the married women. The married women as respondents were selected randomly from each selected village to constitute sample size of 150 respondents.

The Ex-post facto research design was used in the present study, statistically analyzed by using statistical techniques like frequency, percentage. For the study, the interview schedule based on the objectives of the study was prepared for collecting data from the respondents.

The main objectives of this study include adoption of health and nutritional practices by farm women.

\section{Results and Discussion}

The bird eye view of the data presented in table 1 indicated that, amongst health practices for children, cent per cent of the respondents were adopted the practices of immunization of the child, bathing the child daily and giving the child enough safe water complete way respectively. It was followed by the respondents 36.66 and 43.33 who were adopted the practice of washing the hands before holding and feeding the baby completely and partially respectively whereas one fifth of the them could not adopted this practice. With regards to the practice of regular health check-up of baby in baby cliniclhealth centre, little less than one fourth $(23.33 \%)$ and little more than half $(52.00 \%)$ of the respondents were adopted this practice completely and partially respectively.

With regards to health practices for adults the farm women who were completely adopted the practices like keeping the house clean by sweeping and swaddling daily, Keeping the food items covered, Washing hands before preparing cooking and taking meal, the diseases caused by mosquitoes, bed bugs, house flies etc. can be prevented by keeping surrounding clean without stagnation, washing vegetables before cutting, trimming nails clean and taking boiledlfiltered water were reported by the respondents $(56.00 \%), \quad(55.33 \%)$, $(53.33 \%),(40.00 \%)(36.66 \%)$ and $(20.00 \%)$ respectively whereas the respondents who were adopted these practices partially were $44.00,44.66,45.33,60.00,63.33$ and 33.33 per cent respectively. The respondents who never adopted the practice of taking boiled/filtered water were reported by 42.67 per cent.

Amongst nutritional practices for child health cent per cent farm women were adopted the breast feeding for infant/baby followed by more than half of the respondents $(54.00 \%)$ 
who were adopted the practice of introducing the solid food like kichri rice dal to 7 months old child whereas less than half of the respondents $(46.00 \%)$ adopted this practice partially. With regards to consumption of rice, dal and vegetables for child, introducing of milk and milk products or eggs and egg products for growing child and introducing small quantities of soup, juices, kheer etc. to baby's diet at 3 month stage were completely adopted by the respondents $42.00,38.00$ and 35.33 per cent respectively.

The respondents who were adopted these practices in partial form were $36.66,48.66$, and 42.00 per cent respectively whereas 21.33 , 13.33 and 22.67 per cent of them were not adopted these practices at all.

Table.1 Distribution of the respondents according to their practice-wise adoption

\begin{tabular}{|c|c|c|c|c|c|c|c|}
\hline \multirow[t]{3}{*}{ Sr. No } & \multirow[t]{3}{*}{ Statements } & \multicolumn{6}{|c|}{ Respondents (n=150) } \\
\hline & & \multicolumn{2}{|c|}{ Complete adoption } & \multicolumn{2}{|c|}{ Partial adoption } & \multicolumn{2}{|c|}{ Non adoption } \\
\hline & & $\mathbf{F}$ & $\mathbf{P}$ & $\mathbf{F}$ & $\mathbf{P}$ & $\mathbf{F}$ & $\mathbf{P}$ \\
\hline A & Health practices for children & & & & & & \\
\hline 1 & Immunization of child & 150 & 100 & & & & \\
\hline 2 & Bathing the child daily. & 150 & 100 & & & & \\
\hline 3 & Giving of water to the child for drinking regularly & 150 & 100 & & & & \\
\hline 4 & Washing the hands before holding and feeding the baby. & 55 & 36.66 & 65 & 43.33 & 30 & 20 \\
\hline 5 & $\begin{array}{l}\text { Regular health check-up of baby in baby cliniclhealth } \\
\text { centre }\end{array}$ & 35 & 23.33 & 78 & 52.00 & 37 & 24.66 \\
\hline B & Health practices for adults & & & & & & \\
\hline 6 & $\begin{array}{l}\text { Keeping the house clean by sweeping and swabbing } \\
\text { daily. }\end{array}$ & 84 & 56 & 66 & 44 & & \\
\hline 7 & $\begin{array}{l}\text { The diseases caused by mosquitoes, bed bugs, house } \\
\text { flies etc. can be prevented by keeping surrounding clean } \\
\text { without stagnation }\end{array}$ & 80 & 53.33 & 70 & 46.66 & & \\
\hline 8 & Trimming nails clean & 55 & 36.66 & 95 & 63.33 & & \\
\hline 9 & Taking boiledlfiltered water. & 30 & 20.00 & 50 & 33.33 & 64 & 42.67 \\
\hline 10 & Keeping the food articles/items covered & 83 & 55.33 & 67 & 44.66 & & \\
\hline 11 & Washing vegetables before cutting. & 60 & 40.00 & 90 & 60 & & \\
\hline 12 & $\begin{array}{l}\text { Washing hands before preparing cooking and taking } \\
\text { meal. }\end{array}$ & 82 & 54.66 & 68 & 45.33 & & \\
\hline C & Nutrition practices for child health & & & & & & \\
\hline 13 & Colostrums given to new born baby & 86 & 57.33 & 64 & 42.66 & & \\
\hline 14 & Breast feeding for infantlbaby & 150 & 100 & & & & \\
\hline 15 & $\begin{array}{l}\text { Introducing solid food like(kichri/ricedal) is given to } \\
7 \text { month age old child }\end{array}$ & 81 & 54.00 & 69 & 46 & & \\
\hline 16 & Consumption of rice, dal and vegetables is 1 for child. & 63 & 42.00 & 55 & 36.66 & 32 & 21.33 \\
\hline 17 & $\begin{array}{l}\text { Introducing small quantities of soup, juices, kheer etc. to } \\
\text { baby's diet at } 3 \text { month stage }\end{array}$ & 53 & 35.33 & 63 & 42 & 34 & 22.67 \\
\hline 18 & $\begin{array}{l}\text { Introducing milk and milk products or eggs and eggs } \\
\text { products for growing child. }\end{array}$ & 57 & 38 & 73 & 48.66 & 20 & 13.33 \\
\hline D & Nutritional practices for adults & & & & & & \\
\hline 19 & Consumption of green leafy vegetables in the diet & 83 & 55.33 & 38 & 25.33 & 29 & 19.33 \\
\hline 20 & Consumption of sprouted pulse & 33 & 22 & 67 & 44.66 & 47 & 31.33 \\
\hline 21 & $\begin{array}{l}\text { Consumption of cereal-pulses combination in regular } \\
\text { diet. }\end{array}$ & 120 & 80 & 30 & 20 & & \\
\hline 22 & Consumption of milk and curds. & 43 & 28.66 & 56 & 37.33 & 51 & 34 \\
\hline 23 & Using jaggery often in the diet & 25 & 16.66 & 30 & 20 & 95 & 63.33 \\
\hline 24 & Consumption of fruits. & 40 & 26.66 & 74 & 49.33 & 36 & 24 \\
\hline 25 & Drinking 4-5 liters of water daily & 30 & 20 & 49 & 32.66 & 71 & 47.33 \\
\hline 26 & $\begin{array}{l}\text { Mixing of soybean with Jowar and wheat during } \\
\text { grinding. }\end{array}$ & 45 & 30 & 54 & 36 & 51 & 34 \\
\hline
\end{tabular}


Table.2 Distribution of respondents according to their adoption level about health and nutritional practices

\begin{tabular}{|c|c|c|c|}
\hline \multirow{2}{*}{ Sr. No. } & Category & \multicolumn{2}{|c|}{ Respondents $(\mathbf{n = 1 5 0})$} \\
\cline { 2 - 4 } & & Frequency & Percentage \\
\hline 1 & Low & 35 & 23.33 \\
\hline 2 & Medium & 77 & 51.33 \\
\hline 3 & High & 38 & 25.33 \\
\hline
\end{tabular}

As far as nutritional practices for adults are concerned, large majority of the respondents $(80.00 \%)$ were adopted the practice of consumption of cereals-pulses combination in regular diet in complete manner followed by only one fifth of the respondents who were adopted this practice partially.

More than half $(55.33 \%)$ of the farm women adopted the practice of consumption of green leafy vegetables in the diet completely followed by little more than one fourth $(25.33 \%)$ were adopted this practice partially and little less than one fifth $(19.33 \%)$ were not adopted. The majority of the respondents $(63.33 \%)$ were not used jaggery often in the diet whereas, only 26.66 and one fifth of the respondents were used this practice in complete and partial form.

The practices like mixing of soybean with Jowar and wheat during grinding, consumption of milk and curd, consumption of fruits, consumption of sprouted pulse, and drinking 4-5 liters of water daily were adopted completely by the respondents 30.00 , 28.66, 26.66, 22.00 and 20.00 per cent respectively whereas the respondents who were adopted these practices partially were $36.00,37.33,49.33,44.66$ and 32.66 per cent respectively and remaining of the respondents were not adopted these practices.

From the above findings it can be concluded that majority of the respondents were adopted about health practices of child and health practices of adults compared to nutritional practices of child and nutritional practices for adults.

\section{Adoption level}

It could be seen form table 2 that little more than half $(51.33 \%)$ of the respondents were observed in medium level of adoption followed by little more than one fourth, $(25.33 \%)$ of the respondents who were observed in high level and the remaining 23.33 per cent were having low adoption level regarding health and nutritional practices.

From the above findings it can be concluded that maximum number of the respondents were adopted the health and nutritional practices at medium extent.

Majority (64.00\%) of the farm women respondents were medium level of adoption about health and nutritional practices whereas, 17.33 per cent and 18.66 per cent completely adopted and not adopted the health and nutritional practices respectively.

\section{References}

Ashwini Shintre 2009. Attitude of women members towards self-help group. M.Sc. (Agri.) Thesis (Unpub.), Dr. PDKV, Akola.

Kiran Vani 2007. Knowledge and Adoption of Selected Health and Nutritional Practices by Rural Women in Belgaum District, Karanataka M.Sc.(Agri.) Thesis (unpub), Uni. of Agril. Sciences, 
Dharwad.

Swetha Suman, Usha Malagi, Rama K. Naik and Hasabi, I.S. 2007. Clinical health status prevailing complications among chronic renal failure patients. The Ind. J. Nut. Dietics. 44: 236 - 243.

\section{How to cite this article:}

Dhoke, S.P., Y.B. Shambharkar, V.G. Dhulgand and Nair, R.G. 2018. Adoption of Health and Nutritional Practices by Farm Women. Int.J.Curr.Microbiol.App.Sci. 7(01): 1816-1820.

doi: https://doi.org/10.20546/ijcmas.2018.701.220 